\title{
The European Union's Influence over Media Discourse on Renewable Energy Sources in Russia
}

\author{
Marianna Poberezhskaya
}

\begin{abstract}
This chapter looks at how renewable energy discourse in Russian media has been influenced by the prolonged and intricate EU-Russia energy relationship that was substantially intensified after the EU's Eastern Enlargement of 2004. Through the analysis of news articles published by the Internet news agency RIA Novosti over 10 years (2004-2013), it has been concluded that in publications referring to renewable energy sources (RES), the frame of 'Europeanization' occupies one third of the studied material. Whenever the EU enters the discussion, renewable energy sources are discussed as a solution in combating environmental degradation, a cause for cooperation, or another way to provide energy security. It is argued that, among other factors, the EU plays a positive role in the popularization of RES in Russian media discourse.
\end{abstract}

\section{Keywords}

Russia, media discourse, renewable energy sources, energy security, frame analysis

\section{Introduction}

On 22 March 2013, the "Roadmap of EU-Russia Energy Cooperation until 2050"1 was signed in Moscow. The first paragraph of the document emphasizes the mutual importance that Russia and the European Union (EU) represent for each other with regards to their energy security. ${ }^{2}$ The Roadmap became a logical continuation of Russia and the EU's significant energy interdependency and relations which have lasted for several decades. ${ }^{3}$ One could state that these relations intensified following the EU's Eastern Enlargement in 2004. This was influenced by the accession of countries significantly dependent on Russian fossil fuels. For instance, 36 percent of the EU's total gas imports came from Russia at the time of the Roadmap, ${ }^{5}$ whilst in Poland 62 percent of its overall gas supply comes from Russia and in the Baltic States this figure reaches up to 100 percent during the first five years of their accession to the EU. ${ }^{6}$ It could be argued that after the 2004 accession, the continuous energy dependency has also influenced the EU's interest in the development of renewable energy sources (RES) in Russia.

Indeed, in the Roadmap, one out of seven sections is solely devoted to RES, which states that EU-Russia cooperation in the renewable sector will benefit both sides. Russia will be able to use the EU's experience for advancing the national legislature in this area as well as receive access to the latest technologies and knowledge in the field. The EU will gain access to a new market for these products and services. Furthermore, since more Russian energy will be available for export,

\footnotetext{
"Roadmap EU-Russia Energy Cooperation until 2050" (2013), available at $<$ http://ec.europa.eu/energy/international/russia/doc/2013_03_eu_russia_roadmap_2050_signed.pdf $>$.

3 Debra Johnson, "Russia-EU Energy Links", in Debra Johnson and Paul Robinson (eds.) Perspectives on EU-Russia Relations (Routledge, Oxon, 2005), 164-182.

4 Surely, the ongoing conflict in Ukraine followed by the EU's economic sanctions against Russia challenged the very nature of the EU-Russia cooperation schemes. Nevertheless, the analytical framework presented in this chapter remains relevant in addition to the legal arrangements which the EU and Russia continue to observe. See the introductory chapter to this volume by Tom Hashimoto and Michael Rhimes.

5 European Commission (2013) "EU-Russia Energy Relations", available at $<$ http://ec.europa.eu/energy/international/russia/russia_en.htm>.

6 Indra Overland and Heidi Kjarnet, Russian Renewable Energy: The Potential for International Cooperation (Ashgate, Surrey, 2009).
} 
"the availability of Russian [RES], and [...] 'green energy', could contribute to reducing costs for energy, including electricity in the EU."7

The Roadmap does not directly commit Russia to any legal steps ${ }^{8}$ with regards to improvements in energy efficiency, however, it could be argued that from a normative perspective this agreement forces Russia to accept some EU norms or positions; for instance, the perception of RES as an energy source of the future. Interestingly, the Roadmap states that one of the barriers hindering the development of RES in Russia is the "information barrier" which includes a disparity in the levels of general public awareness of the benefits of renewable energy.

Through the application of frame analysis, this chapter explores how EU-Russian energy relations after the 2004 Eastern Enlargement have influenced the discourse on RES in Russian mass media. As further demonstrated, one third of the studied news articles dedicated to RES were dominated by EU-related frames. This led to the development of an argument detailing the EU's positive contribution in stimulating the popularization of RES in Russian media space. This can be considered one of the 'unexpected results' (or 'spillover effects'") of the EU's Eastern expansion and its growing dependency on Russia's energy resources.

The chapter proceeds by contextualizing Russian and EU approaches to the development of RES, a theoretical and methodological discussion, and the presentation of the analyzed data. It concludes with an analytical discussion on the EU's role in framing Russian media discourse on RES.

\section{Context}

The Russian economy, with its heavy reliance on fossil fuel extraction, produces one of the greatest amount of greenhouse gas (GHG) emissions per unit of GDP in the world. In fact, the carbon intensity of Russia's economy exceeds European countries by 3.8 times $^{10}$ and the world average by 2.3 times. $^{11}$ This has led to two negative outcomes. Firstly, over-relying on one type of export good has made Russia's "monocultural" economy very vulnerable ${ }^{12}$ to changes in global economic climate and fossil fuel market. Secondly, it has made Russia one of the most heavily polluting countries in the world. ${ }^{13}$ Both problems could be alleviated through the development of Russian RES which can diversify its energy market and at the same time unlock the country's vast potential for economic de-carbonization, ${ }^{14}$ benefiting both Russia's economic development and global GHG reduction goals. Russia falls far behind the majority of both developed and developing countries in utilizing renewable energy despite its capacity. ${ }^{15}$ For example, all regions in Russia can develop and

\footnotetext{
"Roadmap", op. cit. note 1, 22.

8 Russian environmental law as well as the role of law in Russia's environmental policy present an interesting and fascinating area of research, starting with the detention of Greenpeace activists (who tried to prevent the exploitation of the Arctic by Russian companies) and finishing with a high profile case of Khimkinskiy forest (which has resulted in a series of law suits), however, it is very difficult to determine the influence of EU politics over Russian environmental legal activism. A more substantial study is required.

9 See Carsten Stroby-Jensen, "Neofunctionalist Theories and the Development of European Social and Labour Market Policy”, 38(1) Journal of Common Market Studies (2000), 71-92.

10 Renat Perelet, Sergey Pegov and Mikhail Yulkin, “Climate Change: Russia Country Paper”, Human Development Report 2007/2008 (2007), 10.

11 Vyacheslav Kulagin, "Energy Efficiency and Development of Renewables: Russia’s Approach", 46 Russian Analytical Digest (2008), 2-8, at 2.

12 Sergey Aleksashenko, "Russia's Economic Agenda", 88(1) International Affairs (2012), 31-48, at 43.

13 CRS, "Greenhouse Gas Emissions: Perspectives on the Top 20 Emitters and Developed versus Developing Nations”, Report for Congress: RL32721 (2008).

14 A.T. Bagirov and Georgiy Safonov, Energobezopasnost' i Klimat: Global'nye Vyzovy dlia Rossii (Energy Security and Climate: Global Challenge for Russia) (Teis, Moscow, 2010); and Overland and Kjarnet, op. cit. note 6.

15 Overland and Kjarnet, op. cit.. note 6, 7; and V.P. Shuiskii, S.S. Alabyan, A.V. Komissarov and O.V. Morozenkova "The Global Markets of Renewable Energy Sources and the National Interests of Russia", 21(3) Studies on Russian Economic Development (2010), 318-327.
} 
utilize at least one form of renewable energy, such that it "corresponds to about 30 percent of the country's actual total primary energy supply." 16

In Russia's 2020 Energy Strategy, ${ }^{17}$ RES is seen as a way to ensure energy supplies in regions with "decentralized energy supply systems" (such as the far north of Siberia), or in regions where the centralized energy supplying system does exist but the region experiences "a deficit of energy." An IEA report on Russia's RES states that even though Russia is one of the greatest exporters of fossil fuels in the world, the distribution of the fossil fuels within the country is not equal. ${ }^{18}$ This causes energy poor regions to import fossil fuels from those that have such resources in excess. For example, the Arkhangelsk region has to import coal and oil for its industrial needs from other regions in Russia. ${ }^{19}$

Development of RES in Russia is also seen as a solution to environmental problems. ${ }^{20}$ Based on the calculations of the technical and economic potential of RES in Russia, Overland and $\mathrm{Kjarnet}^{21}$ state that RES development could help Russia to pledge much tougher GHG reduction commitments without any economic sacrifice. The reduction of GHG is also important in terms of the EU's environmental interests and EU-Russia relations. For instance, the EU became the key actor negotiating with Russia on signing the Kyoto Protocol. Arguably, the main reason for Russia's eventual ratification of the Protocol in 2004 was the EU's encouragement, by offering Russia various compromises and benefits from signing the agreement. ${ }^{22}$

Besides international climate change mitigation policy, the EU's interest in developing Russian RES concerns the problem of the EU's own level of GHG emissions. Boute and Willems highlight the fact that the "Directive 2009/28/EC on Renewable Energy makes it possible for member states to achieve their target by improving electricity produced from [RES] from non-EU countries." ${ }^{23}$ Thus, EU Member States can contribute towards developing RES in Russia, and in the instances when electricity produced by these energy sources will be consumed by EU states, it can count towards their national strategies for GHG emissions reductions. Overland and Kjarnet's ${ }^{24}$ database on all existing international renewable energy projects in Russia demonstrates that the majority (more than 45 projects) are supported by the EU or individual EU Member States (predominately Finland and Sweden).

Overall, in the last decade we can observe an increasing interest in developing RES in Russia. The Russian Energy Strategy aims to increase the share of RES by up to 4.5 percent by 2020, this initiative was also supported by the acceptance of a Presidential Decree, the government resolution, as well as the Federal Law on energy efficiency. ${ }^{25}$ As has been suggested, one of the

16 International Energy Agency, Renewables in Russia: from Opportunity to Reality (OECD/IEA, Paris, 2003 ), 9.

17 Ministry of Energy of the Russian Federation, "The Summary of the Energy Strategy of Russia for the Period of up to 2020" (2003), available at <http://ec.europa.eu/energy/russia/events/doc/2003_strategy_2020_en.pdf>.

18 International Energy Agency, op. cit. note, 16, 10; and O.S. Popel', "Vozobnovliaemye Istochniki Energii v Regionakh Rossiyskoy Federatsii: Problemy i Perspecktivy" (Renewable Energy Sources in the Regions of Russian Federation: Problems and Prospects), 5(18) Energosvet (2011), 1-7.

19 Barbara Buchner and Silvia Dall'Olio, "Russia and the Kyoto Protocol: The Long Road to Ratification", 12 Transition Studies Review (2005), 349-382, at 363.

20 Ministry of Energy of the Russian Federation, op. cit. note 17.

21 Overland and Kjarnet, op. cit. note 6, 5.

22 Stavros Afionis and Ioannis Chatzopoulos, "Russia's Role in UNFCCC Negotiations Since the Exit of the United States in 2001", 10 International Environmental Agreements-Politics Law and Economics (2010), 45-63; Liliana Andonova, "The Climate Regime and Domestic Politics: the Case of Russia", 21 Cambridge Review of International Affairs (2008), 483-504; and Laura Henry and Vladimir Douhovnikoff, "Environmental Issues in Russia", 33 Annual Review of Environment and Resources (2008), 437-460.

23 Anatole Boute and Patrick Willems, "RUSTEC: Greening Europe's Energy Supply by Developing Russia's Renewable Energy Potential”, 51 Energy Policy (2012), 618-629, at 618; see also International Finance Corporation, "Renewable Energy Policy in Russia: Waking the Green Giant" (International Finance Corporation, Washington, 2011).

24 Overland and Kjarnet, op. cit. note 6.

25 President of the Russian Federation, "On Some Measures to Improve Energy and Environmental Performance of the Russian Economy”, Decree No.889 (4 June 2008); Government of the Russian Federation, Resolution no. 1-r "[O]n the Main Directions for the State Policy to Improve the Energy Efficiency of the Electricity Sector on the Basis of 
possible reasons for Russia's growing interest in RES is the external influence of the EU, where the energy cooperation between Russia and the EU leads to the unexpected outcomes of promoting a more sustainable energy strategy in Russia. These 'unexpected outcomes' can be explained through the 'spillover' effect.

\section{Theoretical Approach}

The 'spillover' effect is a key concept in one of the grand theories aiming to explain the peculiarities of European integration: Neo-Functionalism. This theory, originally introduced by Ernst Haas, ${ }^{26}$ suggests that regional integration should be understood in a more complex and broader sense, considering all the processes happening amongst various interest groups and nonstate actors. The nature of some of these processes can be described through the concept of 'spillover', which refers to a situation when a political step requires a series of additional steps in order to achieve the original goal, therefore, involving in the process more and more political spheres and actors. ${ }^{27}$ Stroby-Jensen ${ }^{28}$ notes that the 'spillover processes' are usually divided into ones which are caused by some technicalities ('functional spillover') and the ones which have a more "political nature" ('political spillover'). ${ }^{29}$ 'Functional spillover' suggests that "projects of integration engender new problems which, in turn, can only be solved by further integration" 30 in a related area. The classic example of the 'functional spillover' is the creation of the European Coal and Steel Community, which led to the coordination of EU Member States' energy markets, currency exchange rates and so on. ${ }^{31}$ The 'political spillover' concerns ideas, interests and ideologies of the interested parties rather than economic or technical necessities: "actors who have interests in a political initiative in one area support other actors which have interests in different areas and vice versa." 32

Whilst the concept of 'spillover' is usually utilized in order to explain the integration processes happening inside the EU, ${ }^{33}$ and in some cases processes connected with the EU's prospective members (enlargement process), ${ }^{34}$ in this chapter the idea of 'spillover' will be applied to the EU's external relations. It has been hypothesized that EU influence over media discourse on Russian RES is the result of the 'spillover effect' of the EU's increasing dependence on Russia's energy market. Hence, even though EU-Russian energy relations have traditionally been discussed with regards to gas trade, it is argued here that EU influence has not been restricted to the development of hydrocarbon trade with Russia. Rather, it also concerns Russia's domestic development of RES, or in this case, with the framing of media discourse on RES in Russia.

\section{Methodological Considerations}

Renewable Energy Sources for the Period up to 2020" (8 January 2009); and Government of the Russian Federation, Federal Law N261-FZ “On Energy Saving and Energy Efficiency” (23 November 2009).

26 Ernst Haas, The Uniting of Europe: Political, Social and Economic Forces, 1950-1957 (Stanford University Press, Stanford, 1958).

27 Stroby-Jensen, op. cit. note 9, 74.

28 Ibid., 74.

29 See also Neil Nugent, The Government and Politics of the European Union, 7th edition (Palgrave Macmillan, Basingstoke, 2010).

30 Jeppe Tranholm-Mikkelsen (1991), cited in Catherine Macmillan, "The Application of Neofunctionalism to the Enlargement Process: the Case of Turkey", 47(4) Journal of Common Market Studies (2009), 789-809, at 791; and Lisbet Hooghe and Gary Marks, "The Neofunctionalists were (Almost) Right: Politicisation and European Integration", 55 Constitutional Web Papers (2005), available at $<$ https://www.wiso.unihamburg.de/fileadmin/sowi/politik/governance/ConWeb_Papers/conweb5-2005.pdf>.

31 Mark Pollack, "Theorising EU Policy-Making”, in Helen Wallace, Mark Pollack and Alasdair Young (eds.), PolicyMaking in the European Union (Oxford University Press, Oxford, 2010), 15-44.

32 Stroby-Jensen, op. cit. note 9, 74.

33 Arne Niemann, Explaining Decisions in the European Union (Cambridge University Press, Cambridge, 2006).

34 Macmillan, op. cit. note 30. 
This study is based on an analysis of news articles published by the Russian international news agency RIA Novosti. The information agencies lead the hierarchy of information sources in Russia. ${ }^{35}$ RIA Novosti, being one of the largest agencies in Russia, informs a wide variety of societal groups (e.g. national and foreign mass media, the presidential administration, Russian central and regional governments, NGOs, business organizations, and ordinary people). ${ }^{36}$ The analyzed data was accessed through the RIA Novosti website, the search being restricted by the keywords "renewable energy sources" (vozobnovliaemye istochniki energii) and the time-frame 2004-2013. Overall, the search generated 957 news items. The data was narrowed down to a research sample of 100 news articles (by the random selection of 10 news articles from each year).

In order to identify whether there is any EU influence over Russian discourse on RES, this chapter applies the frame analysis to the news on RES published by RIA Novosti. 'Framing' suggests a representation of the reality, which allows us to underline or undermine certain aspects of it in the (media) text. ${ }^{37}$ The methodological approach of frame analysis enables us to read the hidden messages ('metamessages') ${ }^{38}$ within the text and to unravel how this particular perception of reality was formed. Guo et al. state that frame analysis is "particularly useful [in] transnational comparative media research", for instance, in the identification of "which force - globalization or domestication - has more influence on news media's framing of a given issue." 39

Similarly, this study of media coverage of RES in Russia looks at the influence of three processes, i.e. 'Europeanization', 'Domestication', and 'Internationalization', and each news item was analyzed according to the dominant frames categorized into these three processes. The frame 'Europeanization' refers to EU RES or how the EU influences the growth of RES around the world and in Russia. The news articles which were collated under the frame 'Domestication' look at RES only from the position of Russia without any references to a foreign actor. Lastly, the frame 'Internationalization' is represented by articles bringing in third countries/actors (not Russia or the EU) into the discussion of RES. To identify the central theme in each article, the presence and role of "social players and/or sources" 40 was also studied. Sources were grouped within three categories: 'EU', 'Domestic', and 'International', corresponding to the three frames, contributing to a more precise identification of the dominant (or 'central') frame within the studied texts. Further on, within the primary frame 'Europeanization', four subsidiary frames were identified: 'Environment', 'Energy cooperation', 'Energy security', and 'Economic development' (Figure 1).

\section{Figure 1: Algorithm of Frame Detection}

This algorithm will allow us to test the hypothesis that the EU-Russia energy cooperation after the EU's Eastern Enlargement led to a number of unintended 'spillover' effects such as the growing influence of the EU over Russian media discourse on RES. The methodology applied in this research study is inspired by Gamson and Modigliani's 'media package' approach which sees media texts as a "set of interpretive packages" with the "internal structure" based on "a central organizing idea, or frame." 41 This central idea is often transmitted through linguistic tools such as "metaphor or other symbolic device" used by journalists. ${ }^{42}$ Frames can change and evolve over time

\footnotetext{
35 Olessia Koltsova, News media and power in Russia (Routledge, Oxon, 2006).

36 "O RIA Novosti (About RIA Novosti)", RIA Novosti (2012), available at <http://eco.ria.ru/>.

37 Entman (1993), cited in Rens Vliegenthart and Liesbet van Zoonen "Power to the Frame: Bringing Sociology back to Frame Analysis", 26(2) European Journal of Communication (2011), 101-115, at 105.

38 Deborah Tannen, "Introduction", in Deborah Tannen (ed.), Framing in Discourse (Oxford University Press, New York, 1993), 3-13.

39 Lei Guo, Avery Holton and Sun Ho Jeong, "Transnational Comparative Framing: A Model for an Emerging Framing Approach", 6 International Journal of Communication (2012), 1918-1941, at 1919.

40 Ibid.

41 William Gamson and Andre Modigliani, "Media Discourse and Public Opinion on Nuclear Power: A Constructionist Approach", 95 American Journal of Sociology (1989), 1-37, at 3.

42 Ibid.
} 
due to "structural conditions change," 43 and therefore, the analysis of the way frames have developed in the Russian news illustrates the progression of the EU's role in influencing media discourse.

The single central frame is recognized for one news item (a unit of analysis). However, the same unit can contain multiple subsidiary frames. This frame analysis is text-based, the coding is conducted manually, whilst the frames are determined both deductively and inductively. ${ }^{44}$ The deductive approach suggests finding particular frames in the texts, whilst the inductive approach (which is used to define subsidiary frames) suggests "reconstruct[ing] [frames] from clues in news or interview texts" ${ }^{45}$ making the frame analysis tailored to this particular study.

\section{Analysis}

As the analysis demonstrates, a slight majority of the analyzed news items ( 37 percent) belongs to the frame 'Domestication' (Figure 2). In the majority of those cases, RES were only mentioned among other energy sources which all together contribute to Russia's energy security. The articles that did discuss RES concentrated on Russia's great national geographical and technological capabilities. For example, the discussion of "one in the world" orthogonal turbines ${ }^{46}$ or Russia's great natural resources which allow it to produce sustainable energy almost in any geographical region. ${ }^{47}$ Interestingly, throughout various news items united within this frame, RES are frequently mentioned as a solution to fight "energy poverty" 48 by helping energy poor countries gain access to resources. At the same time, in a few articles, RES are described as a danger to Russia's economic well-being - their development can serve to weaken Russia's position in the international energy market which is supported by the state's fossil fuel industry. ${ }^{49}$ The prioritization of state economic welfare over its sustainable development is not new to Russia. Since the time of the Soviet Union, Russia has continuously sacrificed its environmental protection towards economic stabilization and growth. ${ }^{50}$ The former special adviser to President Boris Yeltsin on environmental and public health affairs, Alexey Yablokov, argues that Russia's natural resources are abused by the government in order to achieve a certain level of economic development. ${ }^{51}$ This statement corresponds with the issues discussed above relating to Russia's dependency on its resources and its reluctant behavior during the international environmental negotiations, ${ }^{52}$ which all arguably contributes to the

43 Gaye Tuchman, "Qualitative Methods in the Study of News", in Klaus Jensen and Nicholas Jankowski (eds.), $A$ Handbook of Qualitative Methodologies for Mass Communications Research (Routledge, London, 1991), 79-92, at 89; and Petr Kratochvil, Petra Cibulkova and Michal Benik, "The EU as a 'Framing Actor': Reflections on Media Debates about EU Foreign Policy”, 49(2) Journal of Common Market Studies (2011), 391-412, at 394.

44 Jorg Matthes, "What's in a Frame? A Content Analysis of Media Framing Studies in the World's Leading Communication Journals", 86(2) Journalism and Mass Communication Quarterly (2009), 349-367.

45 Vliegenthart and van Zoonen, op. cit. note 37, 106.

46 "Posle Desiatiletnego Prostoua v Murmanskoy Oblasti Vvedena v Ekspluatatsiyu Edinstvennaia v Rossii Prilivnaia Elektrostantsiia" (After Ten-Year Stoppage the Only Tidal Power Station in Russia was Commissioned in Murmansk Oblast), RIA Novosti (21 December 2004), available at $<$ http://ria.ru/economy/20041221/766492.html\#ixzz2SiNgbHvC>.

47 "Medvedev Podpisal Postanovlenie o Stimulirovanii Ispol'zovaniia VIE" (Medvedev Signed the Resolution Promoting the RES), RIA Novosti (28 May 2013), available at $<\mathrm{http} / / /$ ria.ru/science/20130528/939904963.html\#ixzz2Wq6UfieL>.

48 "Rossiia Gotovit Pozitsii k Sammitu "Bol'shoy Vos'merki" (Russia is Preparing its Positions for the G-8 Summit), RIA Novosti (4 June 2007), available at <http://ria.ru/analytics/20070604/66629919.html\#ixzz2SoOpmNOG>.

49 “Al'ternativnaia Energetika Mozhet Oslabit' Pozitsii Rossii na Energorunke" (Alternative Energy Might Weaken Russia's Position on the Energy Market), RIA Novosti (16 October 2008), available at $<$ http://ria.ru/economy/20081016/153275297.html\#ixzz2SoZRdUAG>.

50 Henry and Douhovnikoff, op. cit. note 22; Laura Henry, "Between Transnationalism and State Power: the Development of Russia's Post-Soviet Environmental Movement", 19 Environmental Politics (2010), 756-781; and Boris Porfiriev, "Environmental Policy in Russia: Economic, Legal and Organisational Issues", 21(2) Environmental Management (1997), 147-157.

51 Alexey Yablokov, "The Environment and Politics in Russia”, 79 Russian Analytical Digest (2010), 2-4, at 3.

52 Marianna Poberezhskaya, Communicating Climate Change in Russia: State and Propaganda. (Routledge, 
perception of RES as an economic issue rather than an environmental one. Therefore, these factors make them vulnerable to any changes in Russia's economic situation. For instance, economic sanctions imposed by the EU as a result of Russia's involvement in the Ukrainian military conflict, could postpone any environmentally-oriented policy. In this case, RES will be considered only if they bring clear economic benefits.

\section{Figure 2: Central Frames within the Analyzed Texts}

The second popular frame 'Internationalization' (34 percent) united news items which discussed RES in relation to countries outside of the EU. The prevailing theme in this group is RES as another item of international cooperation through exchange of technologies and experiences in this field, ${ }^{53}$ as well as an acknowledgment of global energy interdependence and the fragile nature of global energy security. ${ }^{54}$ Within this frame, RES were largely discussed as a solution to the world's environmental problems, especially, climate change. However, the most frequent and adequate discussion of RES within environmental discourse is presented within the frame of 'Europeanization.'

As the data shows, the frame 'Europeanization' is slightly less popular than the other two. Nevertheless, it does not fall too far behind with 29 percent of news items included in this category. As Figure 3 demonstrates, this frame had a slight increase after the first few years (within the studied time-frame). Overall, it has stayed quite stable, occupying just under one third of the studied articles.

\section{Figure 3: Development of the Central Frames over Time}

As has been mentioned before, four subsidiary frames were identified here: 'Economic development', 'Energy security', 'Energy cooperation', and 'Environment' (Figure 4). The first three subsidiary frames have been discussed and briefly described with regards to the other two primary frames of 'Domestication' and 'Internationalization.' In the case of 'Europeanization', the concepts of 'Economic development', 'Energy security' and 'Energy cooperation' were discussed in a similar way to the frames 'Domestication' and 'Internationalization.' For example, the issue of energy security is discussed within the context of EU Member States' vulnerability and their dependency on imported hydrocarbons, and RES capacity to provide a safety net: "we intend to develop our own energy sources in the UK. It will protect us from the shocking measures from the past." ${ }^{55}$ The subsidiary frame 'Energy cooperation' stresses the EU's willingness and capabilities to cooperate with the rest of the world and particularly with Russia. Cooperation has for instance taken the form of investments in the Russian renewable energy sector under the European Neighborhood Partnership Instrument (ENPI) policy ${ }^{56}$ or within the framework of European energy forum. ${ }^{57}$ The 'Economic development' subsidiary frame can be illustrated by the EU's consideration of the economic aspects of RES development, which have to be environmentally and financially sound. ${ }^{58}$

Abingdon, 2015).

53 "SHOS Namerena Dobivat'sia Ravnopravnogo Mirovogo Finansovogo Poriadka" (SCO Intends to Seek Fair Global Financial Order), RIA Novosti (16 June 2009), available at $<$ http://ria.ru/economy/20090616/174529403.html\#ixzz2Sok59kaT>.

54 "V Belorussii k 2020 Godu Planiruetsia Sokratit' Ezhegodnoe Potreblenie Gaza s 18,4 do 16,9 mlrd kubometrov" (Belarus Plans to Cut Annual Gas Consumption from 18.4 to 16.9 bln Cubic Meters), RIA Novosti (18 August 2004), available at <http://ria.ru/economy/20040818/657280.html\#ixzz2SiTkaHSJ>.

55 “Samaia Bol'shaia v Mire 'Vetrianaia Ferma' Zarabotala v Velikobritanii” (World's Largest Wind Farm Begins to Function in the UK), RIA Novosti (23 September 2010), available at $<$ http://ria.ru/eco/20100923/278618770.html\#ixzz2UhVT21G>.

56 "Vetropark v Nenetskom AO Budet Sozdan pri Podderzhke Programmy Kolarctic" (Wind Park in Nenetsk AO will be Built with the Support of the Kolarctic Program), RIA Novosti (29 December 2012), available at $<$ http://ria.ru/economy/20121229/916717221.html\#ixzz2Wpqm7igu>.

57 "V Rime Otkrulsia Energeticheskiy Forum" (Energy Forum Opens in Rome), RIA Novosti (26 April 2004), available at $<$ http://ria.ru/economy/20040426/577361.html\#ixzz2SiLi4iBs>.

58 "V Shotlandii Razrabotchiki Prilivnykh Energotekhnologiy Poluchat Premiyu" (In Scotland, Developers of Tidal 
Otherwise, the EU Member States should not over-rely on RES since it might weaken their energy security and bring economic loses. ${ }^{59}$ This idea is particularly interesting considering that the EU's energy insecurity is to a great extent influenced by its reliance on Russia's fossil fuels.

\section{Figure 4: Share of the Subsidiary Frames within the Central Frame 'Europeanization'}

The majority of the news articles within the 'Europeanization' frame ( 55 percent) belongs to the subsidiary frame 'Environment' in which RES are often accompanied by the adjectives 'clean', 'environmentally friendly', 'economical', and 'sustainable.' The EU is presented as a leader in developing RES with "the largest share of the investments in RES." ${ }^{60}$ A number of articles also discussed some interesting examples about the use or promotion of RES in EU Member States. For example, the British "eco-mosque" which uses energy only produced by RES; ${ }^{61}$ Spain's decision to invest 2.5 billion Euros in the renewable energy sector; ${ }^{62}$ or Greenpeace's success in achieving a ban on building a new nuclear power station in the UK and popularizing the development of RES. ${ }^{63}$

RES are often discussed as one of the main tools in fighting climate change. Consequently, RES featured in numerous discussions of EU climate change mitigation policy and its "infamous" 20-20-20 strategy aiming to cut EU "polluting emissions by 20 percent by 2020 and increase the share of RES by 20 percent." ${ }^{64}$ Notably, the EU's carbon reduction strategy and a goal to achieve a low carbon society by 2050 heavily depend on the development of renewable energy ${ }^{65}$ In addition to the environmental benefits, this change in energy supply should improve EU energy security, decrease energy costs inside EU Member States and will "create new business opportunities" and have "positive impact on employment and GDP growth." 66

Belyi and Overland in their exploration of Russian and western narratives on RES, argue that "Russia sees sustainable development as an additional opportunity to export more oil and gas, whereas most of the energy-importing states are targeting more ambitious objectives related to climate change." ${ }^{67}$ Kulagin shares the same position and argues that "the threat of global warming does not drive Russian policies. Rather, the main impetus for enhancing energy efficiency is to meet rising energy demands at home and maintain, or even increase, export volumes." ${ }^{68}$ Indeed, considering Russia's concerns with the 'economic cost' of RES development, the EU's strong

Energy Technologies Receive Award), RIA Novosti (3 December 2008), available at

$<\mathrm{http} / / /$ ria.ru/eco/20081203/156401146.html\#ixzz2SoYkoFMg>.

59 "Pol'sha i Chekhiia Namereny Prodvigat' Ideyu Ispol'zovaniia Atomnoy Energii" (Poland and the Czech Republic Intend to Promote the Idea of Nuclear Power Usage), RIA Novosti (16 July 2011), available at $<$ http://ria.ru/eco/20110716/402439774.html\#ixzz2VAqCGLdu>.

60 "Kuliki dlia Anglii i Roditeli dlia Belogo Medvedia (Sandpipers for the UK and Parents for a Polar Bear), RIA Novosti (18 November 2011), available at $<$ http://weekend.ria.ru/resume/20111118/492036878.html\#ixzz2VAporvHX>.

61 "V Manchestere Poiavilas 'Ekologichnaia' Mechet”" ('Environmental' Mosque Opens in Manchester), RIA Novosti (9 July 2008), available at <http://ria.ru/eco/20080709/113634422.html\#ixzz2Sobi2SrD>.

62 “V Ispanii Vveden Nalog na Pokupku 'Griaznukh' Mashin” (Spain Introduces a Tax on Buying 'Dirty' Cars), RIA Novosti (3 August 2007), available at <http://ria.ru/society/20070803/70245882.html\#ixzz2SoOZE4jA>.

63 "Greenpeace Dobilsia Peresmotra Britaniey Resheniia o Stroitel'stve Novykh AES" (Greenpeace Encourages the UK to Reconsider Decisions on Building New Nuclear Power Stations), RIA Novosti (15 February 2007), available at $<$ http://ria.ru/world/20070215/60782858.html\#ixzz2SoQq42AJ $>$.

64 "Sammit ES: Dvoynoy Uspekh Shvedskogo Predsedatel'stva" (EU Summit: Double Success of Swedish Presidency), RIA Novosti (30 October 2009), available at $<$ http://ria.ru/world/20091030/191355689.html\#ixzz2SoiPNUoW>; and "Vesenniy Sammit ES Otkryvaetsia v Bryussele" (EU Spring Summit Starts in Brussels), RIA Novosti (8 March 2007), available at $<$ http://ria.ru/politics/20070308/61717804.html\#ixzz2SoQaYLLy>.

65 European Commission, "A Roadmap for Moving to a Competitive Low Carbon Economy in 2050", COM (2011) 112, (Commission of the European Communities, Brussels, 2011).

66 European Commission, "Renewable Energy Road Map. Renewable Energies in the 21st Century: Building a More Sustainable Future", COM (2006) 848, (Commission of the European Communities, Brussels, 2007).

67 Andrei Belyi and Indra Overland, "New Narratives on Russian Renewable Energy Policy", Revue de l'Energie (2010) No.594, 99-105, at 104.

68 Kulagin, op. cit. note $11,2$. 
reliance on increasing the share of sustainable energy sources contrasts as one of the steps in fighting environmental degradation. In Russia, RES discourse is shaped by the "resource-oriented" nature of its economy. However, the EU brings the environmental aspects of RES development into the Russian media discourse. Arguably, it is EU environmental leadership that has the most influence over RES discourse in Russian media where alternative energy sources are pictured as the necessary attribute of the future sustainable society and economy.

The use of RES in Russia is still handicapped despite Russia's potential to develop its renewable energy sector. Shuiskii et al. note that the reasons for such a reluctant attitude towards the development of RES are the relative cheapness of energy available from hydrocarbons, the imperfect legal framework, as well as "a lack of data on resources, technologies, and possibilities of RES." ${ }^{69}$ Simultaneously, the authors note that this pessimistic situation has started to change. Nonconventional technologies have become more economically competitive due to modifications in ecological requirements for the power stations working on hydrocarbons (getting stricter), as well as the government's increasing interest and willingness to stimulate the development of the renewable energy market in Russia (through the acceptance of necessary laws and decrees).

In addition to these internal changes, some authors argue that the development of Russia's energy efficiency in general and RES in particular, could also be improved from outside by the demonstration of the EU's "good model." 70 Goldthau states that "since existing instruments such as the Dialogue provide no direct lever, the EU has only indirect means to influence changes in domestic Russian policies" such as "encouraging" and "convincing" the Russian government of the benefits of a more sustainable policy. ${ }^{71}$ Kratochvil et al. support the same idea by claiming that the EU behaves as "an attractive actor" by possessing the "ability to radiate its norms to the outside environment, even though this normative transformation may not be the result of an intentional action of the Union, but rather an unforeseen consequence of its existence." ${ }^{72}$ Russia is considered to be quite resistant to EU norms influence. ${ }^{73}$ Yet, as this analysis demonstrates, at least in media coverage of RES, the EU can indeed act as a "good model" by demonstrating how RES can serve as a foundation for the state's future environmental policy, energy efficiency, and growing economy.

\section{Conclusion}

By the use of frame analysis this chapter has explored whether or not we can observe the influence of EU-Russian energy relations since the Eastern Enlargement of 2004 over the Russian media discourse on RES. It has been demonstrated that there is a strong presence of the EU in Russian RES media discourse where almost one third of the published material from the studied sample referred to the Union. Furthermore, the majority of the articles in this category discuss RES with regards to EU environmental leadership, the 'good' practices of the development of renewables in EU Member States or as another item in international cooperation and in particular energy cooperation between the EU and Russia. The research conducted here does not allow us to confirm the degree to which the EU exercises its power over Russian renewable energy policy. However, it can be said that EU policy on RES and its cooperation with Russia in this field does have significant influence over the media coverage of renewable energy. Hence, the EU does contribute to the popularization of RES in Russia which helps to deal with another problem of Russian RES - the reluctant public attitude or lack of awareness of the issue. ${ }^{74}$ This outcome became an 'unexpected

\footnotetext{
Shuiskii et al. op. cit. note 15, 326.

Peter Richards, "European Practices Offer a Good Model for Russia", 46 Russian Analytical Digest (2008), 12-14.

71 Andreas Goldthau, "Improving Russian Energy Efficiency: Next Steps”, 46 Russian Analytical Digest (2008), 9-11.

72 Kratochvil et al., op. cit. note 43, 395.

73 Petr Kratochvil, "The Discursive Resistance to EU-Enticement: The Russian Elite and (the Lack of) Europeanization”, 60(3) Europe-Asia Studies (2008), 397-422.

74 Kseniia Vakhrusheva, "Renewable Energy Globally and in Russia in 2010: When will Russia Commit to Green Energy Possibilities?” (2011), available at

$<$ http://www.bellona.org/articles/articles_2011/renewables_russia_global $>$.
} 
result' or a 'spillover effect' of EU-Russia political relations, and in particular, their intricate and (in some cases) very ambiguous energy policies. Such ambiguity often creates tensions between Russia and the EU's Eastern Member States that are heavily reliant on Russian energy supplies.

Oleg Yanitsky argues that with regards to the Russian environmental policy the "exacerbation of the sometimes difficult relations between Russia and the EU always pushes environmental issues to the side-line", whilst Russia is in great need of "a strategic dialogue with Europe." $" 75$ These conclusions could also be applied to the development of RES in Russia. Though they are already present in EU-Russia energy dialogue, Russian renewables would significantly benefit from a more active and straightforward cooperative policy between these two political actors, at least through even greater coverage of the EU's positive practices in media discourse.

75 Oleg Yanitsky, "The Shift of Environmental Debates in Russia”, 57(6) Current Sociology (2009), 747-766, at 764. 


\section{Bibliography}

Afionis, Stavros and Chatzopoulos, Ioannis. (2010) "Russia's Role in UNFCCC Negotiations Since the Exit of the United States in 2001", 10 International Environmental Agreements-Politics Law and Economics, 45-63.

Aleksashenko, Sergey. (2012) “Russia's Economic Agenda”, 88(1) International Affairs, 31-48.

Andonova, Liliana. (2008) "The Climate Regime and Domestic Politics: the Case of Russia", 21 Cambridge Review of International Affairs, 483-504.

Bagirov, A.T. and Safonov, Georgiy. (2010) Energobezopasnost' i Klimat: Global'nye Vyzovy dlia Rossii (Energy Security and Climate: Global Challenge for Russia) (Teis, Moscow).

Belyi, Andrei and Overland, Indra. (2010) "New Narratives on Russian Renewable Energy Policy", Revue de l'Energie No.594, 99-105.

Boute, Anatole and Willems, Patrick. (2012) "RUSTEC: Greening Europe's Energy Supply by Developing Russia’s Renewable Energy Potential”, 51 Energy Policy, 618-629.

Buchner, Barbara and Dall'Olio, Silvia. (2005) "Russia and the Kyoto Protocol: The Long Road to Ratification", 12 Transition Studies Review, 349-382.

Gamson, William and Modigliani, Andre. (1989) "Media Discourse and Public Opinion on Nuclear Power: a Constructionist Approach”, 95 American Journal of Sociology, 1-37.

Goldthau, Andreas. (2008) "Improving Russian Energy Efficiency: Next Steps", 46 Russian Analytical Digest, 9-11.

Guo, Lei, Holton, Avery and Jeong, Sun Ho. (2012) "Transnational Comparative Framing: A Model for an Emerging Framing Approach", 6 International Journal of Communication, 1918-1941.

Haas, Ernst. (1958) The Uniting of Europe: Political, Social and Economic Forces, 1950-1957 (Stanford University Press, Stanford).

Henry, Laura. (2010) "Between Transnationalism and State Power: the Development of Russia's Post-Soviet Environmental Movement”, 19 Environmental Politics, 756-781.

Henry, Laura and Douhovnikoff, Vladimir. (2008) "Environmental Issues in Russia", 33 Annual Review of Environment and Resources, 437-460.

Hooghe, Lisbet and Marks, Gary. (2005) "The Neofunctionalists were (Almost) Right:

Politicisation and European Integration”, 55 Constitutional Web Papers, available at $<$ https://www.wiso.unihamburg.de/fileadmin/sowi/politik/governance/ConWeb_Papers/conweb5-2005.pdf>.

Johnson, Debra. (2005) "Russia-EU Energy Links", in Johnson, Debra and Robinson, Paul (eds.), Perspectives on EU-Russia Relations (Routledge, Oxon), 164-182.

Koltsova, Olessia. (2006) News Media and Power in Russia (Routledge, Oxon).

Kratochvil, Petr. (2008) "The Discursive Resistance to EU-Enticement: The Russian Elite and (the Lack of) Europeanization", 60(3) Europe-Asia Studies, 397-422. 
Kratochvil, Petr, Cibulkova, Petra and Benik, Michal. (2011) “The EU as a 'Framing Actor': Reflections on Media Debates about EU Foreign Policy", 49(2) Journal of Common Market Studies, 391-412.

Kulagin, Vyacheslav. (2008) "Energy Efficiency and Development of Renewables: Russia's Approach", 46 Russian Analytical Digest, 2-8.

Macmillan, Catherine. (2009) "The Application of Neofunctionalism to the Enlargement Process: the Case of Turkey”, 47(4) Journal of Common Market Studies, 789-809.

Matthes, Jorg. (2009) "What's in a Frame? A Content Analysis of Media Framing Studies in the World's Leading Communication Journals", 86(2) Journalism and Mass Communication Quarterly, 349-367.

Niemann, Arne. (2006) Explaining Decisions in the European Union (Cambridge University Press, Cambridge).

Nugent, Neil. (2010) The Government and Politics of the European Union, 7th edition (Palgrave Macmillan, Basingstoke).

Overland, Indra and Kjarnet, Heidi. (2009) Russian Renewable Energy: The Potential for International Cooperation (Ashgate, Surrey).

Perelet, Renat, Pegov, Sergey and Yulkin, Mikhail. (2007) "Climate Change: Russia Country Paper", Human Development Report 2007/2008.

Poberezhskaya, Marianna. (2015) Communicating Climate Change in Russia: State and Propaganda (Routledge, Abingdon).

Pollack, Mark. (2010) "Theorising EU Policy-Making”, in Wallace, Hellen, Pollack, Mark and Young, Alasdair. (eds.), A Policy-Making in the European Union, (Oxford University Press, Oxford), 15-44.

Popel', O.S. (2011) "Vozobnovliaemye Istochniki Energii v Regionakh Rossiyskoy Federatsii: Problemy i Perspecktivy" (Renewable Energy Sources in the Regions of the Russian Federation: Problems and Prospects), 5(18) Energosvet, 1-7.

Porfiriev, Boris. (1997) "Environmental Policy in Russia: Economic, Legal and Organisational Issues", 21(2) Environmental Management, 147-157.

Richards, Peter. (2008) "European Practices Offer a Good Model for Russia”, 46 Russian Analytical Digest, 12-14.

Shuiskii, V.P., Alabyan, S.S., Komissarov, A.V. and Morozenkova, O.V. (2010) "The Global Markets of Renewable Energy Sources and the National Interests of Russia", 21(3) Studies on Russian Economic Development, 318-327.

Stroby-Jensen, Carsten. (2000) "Neofunctionalist Theories and the Development of European Social and Labour Market Policy”, 38(1) Journal of Common Market Studies, 71-92.

Tannen, Deborah. (1993) “Introduction”, in Tannen, Deborah. (ed.), Framing in Discourse (Oxford University Press, New York), 3-13. 
Tuchman, Gaye. (1991) "Qualitative Methods in the Study of News", in Jensen, Klaus and Jankowski, Nicholas. (eds.), A Handbook of Qualitative Methodologies for Mass Communications Research (Routledge, London), 79-92.

Vakhrusheva, Kseniia. (2011) "Renewable Energy Globally and in Russia in 2010: When will Russia Commit to Green Energy Possibilities?" available at $<\mathrm{http}: / /$ www.bellona.org/articles/articles_2011/renewables_russia_global $>$.

Vliegenthart, Rens and van Zoonen, Liesbet. (2011) "Power to the Frame: Bringing Sociology back to Frame Analysis", 26(2) European Journal of Communication, 101-115.

Yablokov, Alexey. (2010) “The Environment and Politics in Russia”, 79 Russian Analytical Digest, $2-4$.

Yanitsky, Oleg. (2009) “The Shift of Environmental Debates in Russia”, 57(6) Current Sociology, 747-766. 